\title{
JAKOŚĆ ŻYCIA UWARUNKOWANA STANEM ZDROWIA U PACJENTÓW Z WYKONIONĄ STOMIĄ W WYNIKU LECZENIA WYBRANYCH CHORÓB NOWOTWOROWYCH - PRZEGLĄD PIŚMIENNICTWA
}

\section{HEALTH RELATED QUALITY OF LIFE IN PATIENTS WITH A STOMA AS A RESULT OF TREATMENT ON SELECTED NEOPLASTIC DISEASES - A LITERATURE REVIEW}

\author{
Agata Gastecka', Magdalena Tarkowska², Kamil Szeliski', Iwona Głowacka-Mrotek², Monika Buhl', \\ Tomasz Nowikiewicz', Wojciech Zegarski ${ }^{4}$, Tomasz Drewa'

\begin{abstract}
${ }^{1}$ Uniwersytet Mikołaja Kopernika w Toruniu, Collegium Medicum im. Ludwika Rydygiera w Bydgoszczy, Wydział Lekarski, Katedra Urologii ${ }^{2}$ Uniwersytet Mikołaja Kopernika w Toruniu, Collegium Medicum im. Ludwika Rydygiera w Bydgoszczy, Wydział Nauk o Zdrowiu, Katedra i Zakład Laseroterapii Fizjoterapii

${ }^{3}$ Uniwersytet Mikołaja Kopernika w Toruniu, Collegium Medicum im. Ludwika Rydygiera w Bydgoszczy, Wydział Nauk o Zdrowiu, Katedra i Klinika Rehabilitacii

${ }^{4}$ Uniwersytet Mikołaja Kopernika w Toruniu, Collegium Medicum im. Ludwika Rydygiera w Bydgoszczy, Wydział Nauk o Zdrowiu, Katedra Chirurgil Onkologicznej, Oddział Kliniczny Nowotworów Piersii Chirurgii Rekonstrukcyjnej
\end{abstract}

DOI: https://doi.org/10.20883/ppnoz.2019.32

\section{STRESZCZENIE}

Jakość życia uwarunkowana stanem zdrowia (Health Related Quality of Life-HRQOL) jest pojęciem odnoszącym się do subiektywnej samooceny jakości życia pacjenta w zakresie zdrowia, a także choroby i jej leczenia. Tematyka ta stała się w ostatnich latach przedmiotem badań wielu autorów. Leczenie chirurgiczne wybranych chorób nowotworowych, w tym układu pokarmowego, jak i układu moczowego, często skutkuje wyłonieniem stomii. Zmieniony sposób wypróżniania prowadzi do zmian jakości życia w aspekcie funkcjonowania biopsychospołecznego chorego i jego rodziny. Holistyczne podejście do procesu leczenia wymaga podejmowania działań mających na celu poprawę dobrostanu chorego m.in. poprzez zapewnienie skoordynowanej opieki na każdym etapie leczenia. Celem pracy była wieloaspektowa analiza problemów towarzyszących pacjentom z wyłonioną stomią, które wpływają na ocenę HRQOL. Metodą badawczą był przegląd piśmiennictwa dotyczącego jakości życia uwarunkowanej stanem zdrowia w przebiegu raka jelita grubego oraz raka pęcherza moczowego.

Słowa kluczowe: jakość życia, stomia, choroby nowotworowe.

ABSTRACT

Health Related Quality Of Life (HRQOL) is a term referring to a subjective, individual evaluation of a patient's life quality in terms of health and sickness, as well as during treatment. This issue has recently become a subject of research for many authors. Surgical treatment of some cancers, especially those located in the gastrointestinal or urinary systems, often results in a necessity for a stoma surgery. Such alterations in the process of passing stool lead to significant changes in patient's biopsychosocial functioning and may also affect his/her family. Holistic approach to the process of treatment requires taking actions intending to ameliorate the patient's general well-being, e.g. providing the patient with coordinated care on every stage of treatment. The aim of our work was a multifaceted analysis of difficulties associated with stoma surgery and the influence they may have on the HRQOL evaluation. The research method we used in our study was the review of relevant literature concerning the quality of life conditioned by health in patients suffering from colorectal cancer and bladder cancer.

Keywords: quality of life, stoma, cancer.

\section{Wstęp}

Jakość życia jest pojęciem niezwykle trudnym do zdefiniowania. Od czasów starożytnych do współczesności termin ten ewaluował i zmieniał znaczenia. W latach 70. i 80. XX wieku jakość życia utożsamiano z możliwością zaspokojenia potrzeb życiowych. W odniesieniu do medycyny rozpatrywano jakość życia zależną od stanu zdrowia HRQOL (Health Related Quality of Life). W pojęciu ogólnym HRQOL odnosi się do subiektywnej oceny dobrostanu biopsychospołecznego [1, 2]. Komponentami HRQOL jest zdrowie fizyczne, psychiczne, sprawność ruchowa, a także aspekty społecznoekonomiczne i somatyczne [3]. Na współczesnym poziomie medycyny uważa się, że dbałość o dobrą jakość życia chorych, w tym pacjentów leczonych przeciwnowotworowo, jest integralną częścią leczenia [2, 4]

W literaturze coraz częściej podkreśla się znaczenie badań nad jakością życia uwarunkowaną stanem zdrowia 
(HRQOL) u pacjentów ze zdiagnozowaną chorobą nowotworową. Ze względu na długotrwałe, ciężkie i zazwyczaj okaleczające leczenie, niejednokrotnie dochodzi do znacznych zmian w funkcjonowaniu w sferze fizycznej, emocjonalnej oraz społecznej chorego. Zmiany te związane są w szczególności z obniżeniem poziomu własnych oczekiwań oraz świadomą adaptacją zaistniałej sytuacji poprzez wypracowanie strategii radzenia sobie z postępującą i przewlekłą chorobą. Zaobserwowano, iz poziom zaawansowania choroby oraz zastosowane leczenie wpływają na subiektywną ocenę jakości życia [5]. Wydaje się, iż oceniana i porównywana jakość życia w zakresie funkcjonowania pacjenta przed i po zastosowanym leczeniu stanowi istotną informację przede wszystkim u chorych, u których choroba nowotworowa prowadzi do znacznej dysfunkcji narządu lub też konieczności radykalnego jego usunięcia. Wyniki badań w zakresie HRQOL mogą być podstawą do oceny korzyści uzyskiwanych przez chorego w wyniku leczenia i stanowić niezbędne źródło do wprowadzania zmian w zakresie poprawy opieki nad pacjentem chorym przewlekle.

Niedochodową organizacją badawczą zajmującą się między innymi badaniem jakości życia pacjentów leczonych z powodu chorób nowotworowych jest Europejska Organizacja Badania i Leczenia Raka (EORTC) z siedzibą $w$ Belgii. Kwestionariusze udostępnione przez grupę EORTC stanowią podstawowe międzynarodowe narzędzia pomiarowe wykorzystywane do analizy jakości życia pacjentów leczonych przeciwnowotworowo [6]. Kwestionariusz EORTC QLQ C30 jest przeznaczony do pomiaru jakości życia uwarunkowanej stanem zdrowia niezależnie od lokalizacji i stopnia zaawansowania procesu nowotworowego. Do dokładniejszej oceny jakości życia wśród pacjentów ze stwierdzonym rakiem jelita grubego przeznaczony jest moduł QLQ CR29, natomiast u pacjentów ze zdiagnozowanym rakiem pęcherza moczowego - moduł QLQ BLM30 lub QLQ NMIBC24 [7]. Ponadto wykorzystywanymi przez wielu autorów instrumentami służącymi do oceny jakości życia w przebiegu raka pęcherza moczowego są kwestionariusze takie jak: FACT-G wraz z modułem FACT-BI, BCl oraz Short Form-36 [8]. Należy zaznaczyć, iż w 2001 roku został opracowany kwestionariusz Stoma QOL, który uznawany jest za istotne narzędzie do pomiaru HRQOL u osób z wyłonioną stomią, m.in. w wyniku operacyjnego leczenia choroby nowotworowej [9].

\section{Cel}

Celem niniejszej pracy była ocena jakości życia uwarunkowanej stanem zdrowia (HRQOL) u pacjentów poddanych chirurgicznemu leczeniu wybranych nowotworów ukła- du pokarmowego oraz moczowego, u których w wyniku przeprowadzonego zabiegu zaistniała konieczność wyłonienia stomii.

\section{Materiał i metody}

Badanie przeprowadzono, posługując się metodą analizy piśmiennictwa. Dokonano przeglądu dostępnych publikacji zamieszczonych w internetowych, medycznych bazach danych.

\section{Rozwinięcie}

Zachorowalność na nowotwory złośliwe w Polsce na przełomie ostatnich 30 lat wzrosła blisko dwukrotnie [10]. Na podstawie prognoz zachorowalności do 2025 roku szacuje się, iż obserwowany będzie dalszy, systematyczny wzrost nowych zachorowań zarówno u mężczyzn, jak i kobiet [11]. Zgodnie z danymi opublikowanymi przez Krajowy Rejestr Nowotworów rak jelita grubego jest najczęściej występującym nowotworem złośliwym przewodu pokarmowego. Pod względem częstości występowania nowotworów złośliwych na świecie wśród mężczyzn zajmuje trzecie miejsce, wśród kobiet drugie. Z kolei rak pęcherza moczowego jest drugim co do częstości występowania nowotworem złośliwym układu moczowego u mężczyzn. Szacuje się, iż nowotwory złośliwe pęcherza moczowego stanowią 7\% zachorowań u mężczyzn i $2 \%$ u kobiet [12]. Szczególnie niepokojący jest fakt, iż zarówno współczynniki zachorowalności i umieralności na raka jelita grubego, jak i raka pęcherza moczowego wykazują tendencję wzrostową [11, 13].

Leczenie omawianych chorób nowotworowych jest leczeniem skojarzonym. W chorobach nowotworowych układu pokarmowego (rak jelita grubego) oraz układu moczowego (rak pęcherza moczowego) leczenie chirurgiczne często wiąże się z koniecznością wyłonienia stomii $[14,15]$.

Słowo stomia wywodzi się z nomenklatury greckiej i dosłownie oznacza "otwór". W rezultacie jest to zespolenie narządu wewnętrznego ze skórą przedniej powierzchni brzucha. Stomie można podzielić na dwa główne typy: stomie odżywcze oraz odbarczajace. Stomie odżywcze wykorzystuje się do podaży pokarmu w przypadku, gdy pacjent $z$ różnych przyczyn nie jest $w$ stanie przyjmować jedzenia w sposób fizjologiczny. Stomie obarczające wyłaniane są celem ewakuacji treści pokarmowej, moczowej lub kałowej w sposób inny niż fizjologiczny. W zależności od lokalizacji wyłonienia stomii jelitowej wyróżnia się ileostomię (na jelicie cienkim) oraz kolostomię (na jelicie grubym). Stomie wyłonione w obrębie jelita grubego również dzielą się w zależności od lokalizacji na coecostomię - na kątnicy, transversostomię - na poprzecznicy i sigmostomię 
- na esicy. Treść worka stomijnego w przypadku ileostomii i kolostomii jest różna. Kolostomia z wyjątkiem coecostomii zawiera treść kałową, ileostomia treść płynną, nieprzypominającą uformowanego kału [16]. W przypadku układu moczowego wyłoniona zostaje urostomia. Najczęstszym wskazaniem do wyłonienia stałej urostomii jest radykalne leczenie raka pęcherza moczowego [17]. Zabieg radykalnej cystektomii składa się z dwóch etapów. Pierwszy polega na wycięciu pęcherza moczowego wraz ze sterczem, pęcherzykami nasiennymi i węzłami chłonnymi u mężczyzn oraz macicą, przydatkami i węzłami chłonnymi u kobiet [18]. Celem drugiego etapu jest rekonstrukcja dróg moczowych dla zapewnienia prawidłowego odpływu moczu z organizmu, poprzez połączenie wytworzone między drogami moczowymi a skórą. Rekonstrukcja dróg moczowych może zostać wykonana poprzez metody: zapewniające trzymanie moczu (continent reconstructions) oraz niezapewniające trzymania moczu (incontinent reconstructions). Niemniej jednak w praktyce klinicznej, drogi moczowe najczęściej zrekonstruowane zostają poprzez techniki niezapewniające trzymania moczu, co skutkuje koniecznością stałego utrzymywania i pielęgnowania urostomii. Wśród niekontynentnych technik wyróżnia się nadpęcherzowowe odprowadzenie moczu, które polega na odtworzeniu ciągłości dróg moczowych z wykorzystaniem odcinka jelita cienkiego. Zabieg polega na wyizolowaniu pętli jelita, do której z jednej strony wszczepione zostają moczowody, z drugiej zaś moczowody zespolone zostają bezpośrednio ze skórą, tzw. metoda Brickera (ureteroileocutaneostomia). Wstawka jelitowa jest najbardziej rozpowszechnioną metodą rekonstrukcji dróg moczowych wśród pacjentów hospitalizowanych z powodu chirurgicznego leczenia raka pęcherza moczowego. Druga metoda nie narusza ciągłości przewodu pokarmowego i polega na wyłonienieniu moczowodów bezpośrednio do skóry obustronna przetoka moczowodowo-skórna (ureterocutaneostomia) lub jednostronna przetoka moczowodowoskórna z wszczepieniem moczowodu przeciwległego do moczowodu wszczepionego do skóry (transuretero-ureterocutaneostomia) [19, 20, 21, 22]. Urostomia ma na celu zbiórkę moczu i niewielkiej ilości śluzu. Mocz zostaje zebrany do specjalnego worka drenującego zabezpieczonego zatyczką, który należy opróżniać od 4 do 6 razy dziennie i wymieniać co 1-2 dni [23].

Konieczność posiadania stomii wśród pacjentów generuje wiele obaw związanych z późniejszym funkcjonowaniem. Zmienioną fizjologię wypróżnień pacjenci często odbierają jako kalectwo, czują się niepełnowartościowi, prezentują obniżoną samoocenę. Chorzy, u których zaistniała konieczność wyłonienia stomii, odczuwają obawy przed powrotem do funkcji i ról pełnionych przed operacją. Problemy z zaakceptowaniem „nowego obrazu własnego ciała" mogą także być przyczyną zaburzonych relacji interpersonalnych oraz niechęci do podjęcia aktywności seksualnej [24]. Wiele doniesień naukowych z ostatnich lat wskazuje, że jednym z późnych powikłań konieczności wyłonienia stomii może być znacznie obniżona jakość życia pacjenta [25-29]. Saunders podkreśla rolę zespołu terapeutycznego $\mathrm{w}$ procesie adaptacji do zmienionych warunków fizycznych [30].

Ocena jakości życia jest niezwykle istotna dla zrozumienia perspektywy pacjenta i podejmowania decyzji związanych z dalszym leczeniem, bowiem konieczność wyłonienia stomii wpływa na wiele aspektów życia pacjenta [31] Ingerencje chirurgiczne w obrębie jamy brzusznej wiążą się z ryzykiem powikłań, w tym ograniczonej wydolności fizycznej. W konsekwencji powoduje to większą zależność od rodziny i personelu medycznego. Badania Nasvall i wsp. porównujące jakość życia 336 pacjentów z wyłonioną stomią jelitową i 117 bez stomii dowiodły gorszego funkcjonowania w wymiarze fizycznym, emocjonalnym i psychicznym w grupie pacjentów stomijnych. W zakresie skal objawowych, zmęczenie oraz brak łaknienia okazały się być bardziej nasilone także wśród chorych ze stomią [31] Gorszą jakość życia w wymiarze fizycznym i emocjonalnym 'stomików' potwierdzają także doniesienia innych badaczy [25]. Obniżoną jakość życia wśród pacjentów zakwalifikowanych do zabiegu brzuszno-kroczowej resekcji odbytnicy zaobserwowali też inni autorzy [32]. Peng i wsp. przeprowadzając analizę porównawczą wśród 154 pacjentów leczonych z powodu raka jelita grubego z wyłonioną stomią vs. wypróżniających się w sposób fizjologiczny, stwierdzil istotnie statystycznie różnice wyników pomiędzy grupami w zakresie samooceny obrazu własnego ciała z gorszymi wynikami w grupie osób posiadających stomię [33].

Oprócz somatycznych konsekwencji operacji kończącej się wyłonieniem stomii jelitowej doniesienia naukowe wskazują na częste występowanie wśród tych chorych problemów z zaakceptowaniem zmienionych warunków fizycznych związanych z niemożnością wypróżniania się w sposób fizjologiczny [31, 34]. Generuje to problemy natury psychicznej, w tym lęk przed dalszym funkcjonowaniem [31, 34], zatem wszyscy pacjenci już w okresie przedoperacyjnym powinni być poinformowaniu o istnieniu grup wsparcia.

Po leczeniu chirurgicznym, w wyniku którego została wyłoniona stomia jelitowa pacjenci bardzo często ograniczają aktywność społeczną i seksualną. O negatywnym następstwie stomii na jakość życia w zakresie funkcjonowania społecznego wskazują wyniki podłużnych wielo- 
ośrodkowych badań autorstwa Herrle i wsp. [35]. Izolacja ta w opinii Symms MR i wsp. spowodowana jest niechęcia do zmienionego obrazu własnego ciała, utratą atrakcyjności oraz obawą przed wyciekiem treści i gazów z worka stomijengo [36]. Z badań White CA i wsp. wynika, że połowa pacjentów po zabiegu wyłonienia stomii nie podejmuje już aktywności seksualnej [37]. Zaburzenia seksualne mogą być jednym z powikłań resekcji raka jelita grubego, powodując u mężczyzn problemy ze wzwodem, natomiast u kobiet dyspareunię. Wszystko to może wpływać na zmniejszoną satysfakcję i zdolność do współżycia [38]. Wyniki badań innych autorów również dostarczają informacji o częstszym występowaniu problemów seksualnych w grupie pacjentów ze stomią [17, 31].

Podobne trudności, jak w przypadku pacjentów ze stomią jelitową, zaobserwowano u pacjentów urostomijnych. Zarówno mężzzyźni, jak i kobiety z wyłonioną urostomią napotykają na wiele problemów fizycznych oraz społecznych wynikających z utraty funkcji organizmu. Największymi wyzwaniami dla stomików jest radzenie sobie ze stomią i jej urządzeniami, dysfunkcją organizmu, negatywnymi skutkami psychospołecznymi, wsparciem i edukacją, filozofią radzenia i adaptacji $[39,40]$. Chorzy bardzo często postrzegają siebie jako osoby oszpecone. Towarzyszy temu poczucie lęku i bezradności. Niektórzy pacjenci zgłaszają trudności i obawy przed powrotem do aktywności zawodowej, pełnionych funkcji społecznych oraz życia seksualnego $[40,41]$. Ponadto chorzy muszą zmagać się nie tylko z wyzwaniem, jakim jest operacja i stomia, ale także z innymi powikłaniami leczenia [9]. Stwierdzono, iż wynik HRQOL wśród osób z urostomią po zabiegu jest niższy niż u osób z kolostomią lub ileostomią [40, 42].

W badaniu Villa i wsp. przeprowadzonym na 23 pacjentach po radykalnym usunięciu pęcherza moczowego, zidentyfikowano i porównano czynniki wpływające na samopoczucie pacjenta stomijnego tj. wpływ chirurgii, oczekiwaną długość życia i lęk przed nawrotem choroby, obraz ciała, codzienne i towarzyskie aktywności życiowe, utrzymywanie stomii w domu i w pracy, wpływ na seksualność, a także wsparcie pielęgniarek oraz rodziny i przyjaciół. Uzyskane wyniki badania wykazały, iż wielu pacjentów przed zabiegiem chirurgicznym obawiało się pogroszenia stanu zdrowia lub rozwoju innego rodzaju nowotworu, co wpłynęło na spadek pewności siebie. Pomimo tego zabieg chirurgiczny dał nowe możliwości przeżycia, jednak z "ciężarem" komplikacji radzenia w nowej sytuacji. Pacjenci zaznaczyli istotny wpływ urostomii na jakość życia, nie tylko w aspekcie wizerunku ciała, ale i nowych warunków życiowych, jakimi są: funkcje seksualne, trzymanie moczu, opieka stomijna, praca i życie społeczne. Wielu z nich uznało, iż wyłoniona stomia zakłóca funkcjonowanie pod względem estetycznym i psychologicznym. Mimo zmienionych warunków fizycznych pacjenci wyrażali wolę wykonywania czynności, w które byli zaangażowani przed zabiegiem. Zaznaczono, iż kłopotem dla pacjentów było zarządzanie stomią z dala od domu ze względu na obawę przed wyciekiem moczu w miejscach publicznych. Zaobserwowano, iż stomia istotnie wpłynęła na fizyczne (zaburzenia erekcji, zmieniona anatomia pochwy) i psychologiczne (brak atrakcyjności) aspekty seksualności [40].

Podobne wyniki badania uzyskała Walewska i wsp Przeprowadzone badanie dowiodło, iż u 98\% ankietowanych pacjentów, u których mocz odprowadzono sposobem Bricker'a, przetoka utrudniła funkcjonowanie zarówno w życiu rodzinnym, towarzyskim, zawodowym, jak i sferze osobistej i intymnej. Ponadto aż 95\% respondentów stwierdziło, iż największa trudność wynikała z nieszczelności worka stomijnego. W konsekwencji u ponad $37 \%$ z nich skutkowało to poczuciem braku bezpieczeństwa w codziennym życiu. Problemy pacjentów urostomijnych wynikały także z przyczyn edukacyjnych, które nie zostały zrealizowane na etapie szpitalnym. Dotyczyły one głównie aspektów związanych z brakiem możliwości zapoznania się ze sprzętem urostomijnym przed zabiegiem $(65,7 \%)$ oraz samodzielnym zaopatrzeniem przetoki (63\%) [43].

Wpływ urostomii na jakość życia wykazali również Pazar i wsp. w przekrojowym badaniu przeprowadzonym na grupie 24 pacjentów, w tym 95,8\% z powodu raka pęcherza moczowego. Uzyskane wyniki dowiodły, iż większość pacjentów urostomijnych wskazywała, iż wygląda "brzydko" i niatrakcyjnie oraz inaczej niż inni ludzie. Skutkowało to potrzebą ukrycia obecności stomii w niektórych środowiskach oraz poczuciem smutku spowodowanym zmianami w ciele. Największe obawy spowodowane były nieszczelnością i nieprzyjemnym zapachem stomii. Czynniki te przyczyniły się do zmian zachodzących $w$ relacjach z partnerami, m.in. poprzez niechęć pokazywania ciała. Uczestnicy badania jednogłośnie stwierdzili, iż mają problemy z seksualnością. Autorzy badania podkreślili, iz są to wyniki w okresie 4 miesięcy po zabiegu, a skutki operacji mogą utrzymywać się nawet do 18 miesięcy [44].

Nie bez znaczenia pozostaje wpływ jakości snu na jakość życia pacjenta urostomijnego, który zbadali zarówno Cavadar i wsp., jak i Furukawa i wsp. Badania wykazały, iz jakość życia i sen ulegają pogorszeniu u osób z wyłonioną stomią, w tym w odniesieniu do dorosłych w populacji ogólnej $[45,46]$.

Gomez i wsp. w badaniu dotyczącym jakości życia u pacjentów z urostomią podkreślili istotną rolę pielęgniarki w zakresie podejemowania interwencji medycznych 
mających na celu utrzymanie najwyżej możliwej HRQOL [9]. Natomiast Jensen i wsp. dowiedli skuteczności przedoperacyjnej edukacji stomijnej na zdolność jednostki do samodzielnej obsługi urządzenia stomijnego, która stanowi bazę do rehabilitacji pooperacyjnej [47]

Zgodnie z powyższym w procesie zdrowienia niezwykle ważne jest przekazanie wiedzy i nauka umiejętności właściwej pielęgnacji stomii. Potwierdzają to badania, w których stwierdzono związek pomiędzy satysfakcjonującym dla pacjenta przygotowaniem do samopielęgnacji w środowisku domowym, a lepszą jakością życia w wielu wymiarach codziennego funkcjonowania [48]. Glińska podkreśla przede wszystkim rolę edukacyjną pielęgniarki stomijnej sprawującej opiekę nad tą grupą pacjentów. Doniesienia naukowe zwracają uwagę na istnienie newralgicznej grupy pacjentów, którą należy objąć szczególną pomocą edukacyjną. Należą do nich chorzy z niskim wykształceniem [49], osoby w wieku podeszłym [50], pacjenci ze wspótistniejącymi zaburzeniami psychicznymi, chorzy z niekorzystnymi prognozami na przyszłość [51] oraz pacjenci z wyłonioną kolostomią [52]. Badania wskazują, że wraz z wiekiem obniża się jakość życia w sferze środowiskowej i socjalnej [49]. Niebagatelne znaczenie w niwelowaniu lęku przed powrotem do normalnego życia ma fakt przekazania informacji o placówkach medycznych, np. poradnie stomijne, w których pacjent $w$ każdej chwili może uzyskać pomoc. Finlay B. i wsp. zwracają uwagę na fakt, że dobra opieka medyczna realizowana na wszystkich etapach zdrowienia może przyczynić się do poprawy jakości życia chorych, u których zaistniała konieczność wyłonienia stomii jelitowej [53]. W literaturze podkreśla się również związek pomiędzy edukacją dotyczącą wykorzystania akcesoriów stomijnych i aspektów samopielęgnacji sztucznego odbytu, a subiektywną oceną jakości życia uwarunkowanej stanem zdrowia [54]. Nie bez znaczenia jest również koszt związany z zakupem niezbędnych akcesoriów do pielęgnacji. Świadczą o tym wyniki badań Suppamas Maneesin i wsp., w których niższe wydatki przeznaczane na sprzęt stomijny wiązały się z wyższymi wynikami HRQOL [55]. Kluczowe ogniwo opieki ambulatoryjnej stanowią poradnie stomijne, oferujące chorym i ich rodzinom profesjonalne wsparcie oraz pomoc w czynnościach pielęgnacyjnych [56]. Literatura wskazuje, że czynnikami poprawiającymi satysfakcję z życia pacjenta może być udział w rehabilitacji [57] oraz upływający czas od zabiegu [58, 59]. Ławnik A. podkreśla, konieczność objęcia kompleksową i długotrwałą rehabilitacją pacjentów z wyłonioną stomią na różnych etapach zdrowienia. Zdaniem autorki usprawnianie należy realizować nie tylko $w$ sferze fizycznej, ale również biopsychospołecznej [57].
Na długotrwałe obniżenie jakości życia wśród pacjentów operowanych z powodu raka jelita grubego, nawet po upływie 5 lat od zakończenia leczenia wskazują badania van Heinsbergen M. i wsp. [60]. Obniżenie jakości życia niezależnie od rodzaju wyłonionej stomii (czasowa/ stała) potwierdzają także badania innych autorów [61]. Zespół terapeutyczny, planując sposób leczenia pacjenta, powinien uwzględnić także jego preferencje. Wrenn i wsp. w badaniu przekrojowym oceniali, jakie aspekty opiek okołooperacyjnej najbardziej cenią pacjenci. Okazało się, że dla chorych najważniejsza była świadomość „pozbycia się" raka (76\%), brak powikłań (74\%) oraz brak na stałe wyłonionej stomii (78\%). Co ciekawe, dla pacjentów nie było ważne, jaką metodą zostaną operowani, nie liczył się wygląd blizny oraz długość pobytu w szpitalu [62].

\section{Zakończenie}

Badania Kozak G. wskazują, że jakość życia pacjentów leczonych przeciwnowotworowo $w$ dużej mierze zależna jest od rodzaju i lokalizacji nowotworu złośliwego [63]. Doniesienia naukowe wskazują, że dobry wynik leczenia choroby nowotworowej nie może być odzwierciedlony jedynie we wskaźnikach zachorowalności i umieralności, ale również w samoocenie stanu zdrowia i satysfakcji z życia pacjenta [64]. Kimura i wsp. podkreślają konieczność objęcia holistyczną opieką pacjentów stomijnych, ukierunkowaną na skuteczną rehabilitację, poprawę jakości życia oraz udzielenie wsparcia emocjonalnego [65]. Niezwykle ważnym elementem $w$ procesie zdrowienia jest objęcie chorych z wyłonioną stomią interdyscyplinarną opieką świadczoną przez wszystkich członków zespołu terapeutycznego. Świadczą o tym wnioski płynące z opracowania Kapeli i wsp. [28]. Podejmowanie badań dotyczących aspektów jakości życia umożliwia poznanie problemów zdrowotnych determinowanych czynnikami biopsychospołecznymi.

\section{Oświadczenia}

Oświadczenie dotyczące konfliktu interesów

Autorzy deklarują brak konfliktu interesów.

\section{Źródła finansowania}

Autorzy deklarują brak źródeł finansowania.

\section{Piśmiennictwo}

1. Tomalska J, Trytko A, Ogarek D, Schmidt J, Bibro M, Łaczek-Wójtowicz M, Wódka K. Ocena jakości życia kobiet po chirurgicznym leczeniu raka piersi zrzeszonych w klubach amazonek. Pielęgniarstwo XXI wieku; 2012, 4 (41), 85-89.

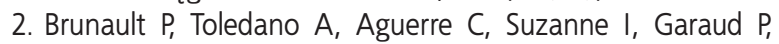
Trzepidur-Edom M, Calais G, Camus V. Impact of late treatment-related radiotherapy toxicity, depression, and anxiety 
on quality of life in long-term breast cancer survivors. Bulletin Du Cancer, 2012, 589-598.

3. Trzebiatowski J. Jakość życia w perspektywie nauk społecznych i medycznych - systematyzacja ujęć definicyjnych. Hygeia Public Health 2011, 46(1): 25-31.

4. De Walden Gałuszko K, Majkowicz M. Jakość życia w chorobie nowotworowej. UG, Gdańsk 1994.

5. Radecka B. Jakość życia uwarunkowana stanem zdrowia znaczenie i sposoby oceny $u$ chorych na nowotwory. Curr Gynecol Oncol, 2015, 13 (3), p. 172-179.

6. Zawisza K, Tobiasz-Adamczyk B, Nowak W, Kulig J, Jędrys J. Trafność i rzetelność oceny kwestionariusza oceny jakości życia EORTC QLQ C30 oraz jego modułu dotyczącego pacjentek z nowotworami piersi EORTC QLQ BR23. Ginekologia Polska. 2010, 81, 262-267.

7. http://groups.eortc.be/qol/eortc-qlq-c30, data dostępu 11.07.2018 r., godz. 22;33.

8. Witjes JA, Compérat E, Cowan NC, De Santis M, Gakis G, James $N$, Lebret T, Sherif A, Van der Heijden AG, Ribal MJ. Guidelines on Muscle-invasive and Metastatic Bladder Cancer. European Association of Urology, 2015; 36-37.

9. Gomez A, Barbera S, Lombraña M, Izquierdo L, Baños C. Health-related quality of life in patients with urostomies. J Wound Ostomy Continence Nurs. 2014 MayJun;41(3):254-6.

10. http://onkologia.org.pl/nowotwory-zlosliwe-jelita-grubego -c18-21/, data dostępu 10.07.2018r., godz. 22:36.

11. Didkowska J, Wojciechowska U, Zatoński W. Prognozy zachorowalności i umieralności na nowotwory w Polsce do 2025 roku. Krajowy Rejestr Nowotworów, Warszawa 2009, $11-12 ; 23 ; 87$.

12. http://onkologia.org.pl/nowotwory-zlosliwe-pecherza-moczowego-c67/, data dostępu 10.07.2018r., godz. 22:36.

13. Potemski P. Epidemiologia, badania przesiewowe i klasyfikacja zaawansowania klinicznego raka jelita grubego. Onkol. Prak. Klin. 2010, 6 (6), 283-289.

14. Nowacki MP, Bujko K. Współczesne poglądy i zasady leczenia chorych na raka dolnej części odbytnicy ; Polski Przegląd Chirurgiczny, 1999, 3;310-317.

15. Rutkowski A, Nowicki MP. Chirurgiczne leczenie raka jelita grubego zlokalizowanego w odbytnicy. [w:] Deptała A, Wojtkiewicz MZ (red.). Rak jelita grubego. Wydawnictwo Medyczne Termedia. Poznań 2012, 137-149.

16. Szczęsny W, Siewkowska M, Dąbrowiecki S, Szmytkowski J. Stomia jelitowa - podział i powikłania. Nursing Topics. 2013, 21 (2), 260-265.

17. Golicki D, Styczeń P, Szczepkowski M. Jakość życia ze stomią w Polsce: wieloośrodkowe badanie przekrojowe z wykorzystaniem kwestionariusza WHOQOL-BREF. Przegl Epidemiol. 2013, 67:589-593.

18. Antoniewicz A, Zapała Ł. Cystektomia radykalna - standard operacji we współczesnej uroonkologii. Przegląd Urologiczny 2011, 2 (66).

19. Gajewska D. Odprowadzenie moczu po cystektomii radykalnej u chorych na raka pęcherza moczowego: rodzaje, kandydaci, wyniki. Przegląd Urologiczny 2015, 2 (90).

20. Antoniewicz A. Analiza przydatności klinicznej własnej metody rekonstrukcji jelitowej pęcherza moczowego u chorych poddanych radykalnemu wycięciu pęcherza z powodu raka. Wydawnictwo Media-Press Sp. z o.o., Warszawa 2013, s. 36-37.

21. Pypno W. Rak pęcherza moczowego. Postępy Nauk Medycznych s1/2014, s. 56-58.

22. Morrison CD, Kielb SJ. Use of Bowel in Reconstructive Urology: What a Colorectal Surgeon Should Know. Clin Colon Rectal Surg. 2017, Jul;30(3):207-214.
23. Burch J. Preoperative care of patients undergoing stoma formation: what the nurse needs to know. Nurs Stand. 2017, May 3; 31(36):40-43.

24. Salomé GM, de Lima JA, de Cássia Muniz K, Faria EC, Masako Ferreira L. Health locus of control, body image and self-esteem in individuals with intestinal stoma. $\mathrm{j}$ coloproctol (rio j) 2017, 3 7(3):216-224.

25. Monastyrska E, Hagner W, Jankowski M, Glowacka I, Zegarska B, Zegarski W. Prospective assessment of the quality of life in patients treated surgically for rectal cancer with lower anterior resection and abdominoperineal resection. EJSO 42 (2016) 1647-1653.

26. Maćkowska B, Kiełb E, Zegarski W. Opieka w terapii nowotworów przewodu pokarmowego. [w:] Koper A. (red.): Pielęgniarstwo onkologiczne. Wydawnictwo Lekarskie PZWL Warszawa 2011, 137-140

27. Szymańska-Pomorska G, Felińczak A, Misiak K, Kuriata-Kowalska K, Śliwińska M, Pytel A. Wybrane aspekty jakości życia pacjentów po wyłonieniu kolostomii. Piel. Zdr. Pul. 2015, 5 (1), 25-31.

28. Kapela I, Bąk E, Krzemińska S, Foltyn A. Ocena poziomu akceptacji choroby i satysfakcji z życia u chorych na raka jelita grubego leczonych chemioterapią. Piel. Zdr. Publ. 2017, 26 (1), 53-61.

29. Plata K, Majewski W. Jakość życia pacjentów po operacji na jelicie grubym z wytworzeniem stomii. Roczniki Pomorskiej Akademii Medycznej w Szczecinie. 2008, 54 (2), 77-85.

30. Saunders RN, Hemingway D. Intestinal stomas, SURGERY 26:8, 347-351.

31. Näsvall P, Dahlstrand U, Löwenmark T, Rutegård J, Gunnarsson U, Strigård K. Quality of life in patients with a permanent stoma after rectal cancer surgery. Qual Life Res. $2017 \mathrm{Ja}$ $n ; 26(1): 55-64$

32. Kasparek MS, Hassan I, Cima RR et al. Quality of life after coloanal anastomosis and abdominoperineal resection for distal cancers: sphincter preservation vs quality of life. 2010 Colorectal Dis 2011;13:872-7.

33. Peng J, Shi D, Goodman K, Goldstein D, Xiao Ch, Guan Z, Cai S Early results of quality of life for curatively treated rectal cancers in Chinese patients with EORTC QLQ-CR29. Radiation Oncology 2011; 6: 93

34. Sharpe L, Patel D, Clarke S. The relationship between body image disturbance and distress in colorectal cancer patients with and without stomas. J Psychosomatic Res 2011, 70:395-402.

35. Herrle F, Sandra-Petrescu F, Weiss C, Post S, Runkel N, Kienle P. Quality of Life and Timing of Stoma Closure in Patients With Rectal Cancer Undergoing Low Anterior Resection With Diverting Stoma: A Multicenter Longitudinal Observational Study. Dis Colon Rectum. 2016, 59(4):281-90.

36. Symms MR, Rawl SM, Grant M, Wendel CS, Coons SJ, Hickey S et al. Sexual health and quality of life among male veterans with intestinal ostomies. Clin Nurse Spec. 2008; 22:30-40.

37. White CA, Hunt JC. Psychological factors in postoperative adjustment to stoma surgery. Ann R CollSurg Engl. 1997; 79:3-7.

38. Kili E TO, Belli AK OM. The Effect of permanent ostomy on body Image, self-esteem, marital adjustment, and sexual functioning. Turk PsikiyatriDerg. 2007, 18:302-10.

39. McMullen CK, Hornbrook MC, Grant M, Baldwin CM, Wendel CS, Mohler MJ, Altschuler A, Ramirez M, Krouse RS. The greatest challenges reported by long-term colorectal cancer survivors with stomas. J Support Oncol. 2008, Apr;6(4):175-82.

40. Villa G, Manara DF, Brancato T, Rocco G, Stievano A, Vellone E, Alvaro R. Life with a urostomy: A phenomenological study. ApplNurs Res. 2018, Feb;39:46-52. 
41. Recalla S, English K, Nazarali R, Mayo S, Miller D, Gray M. Ostomy care and management: a systematic review. J Wound Ostomy Continence Nurs. 2013, Sep-Oct;40(5):489-500.

42. Furukawa C, Sasaki Y, Matsui K, Morioka I. Health-related quality of life and its relevant factors in Japanese patients with a urostomy. J Wound Ostomy Continence Nurs. 2013, Mar-Apr;40(2):165-70.

43. Walewska E, Nowak A, Ścisło L, Orzeł-Nowak A, Szczepanik AM, Czupryna A. Przygotowanie chorego do samoopieki po radykalnym usunięciu pęcherza moczowego. Via Medica, Problemy Pielęgniarstwa 2013, 21 (1):72-78.

44. Pazar B, Yava A, Başal S.. Health-related quality of life in persons living with a urostomy.J Wound Ostomy Continence Nurs. 2015, May-Jun;42(3):264-70.

45. Cavdar I, Temiz Z, Ozbas A, Can G, Tarhan F, Findik UY, Kutlu FY, Akyuz N. Sleep and quality of life in people with ileal conduit. Scand J Urol. 2016, Dec;50(6):472-476.

46. Furukawa C, Morioka I. Health-Related Quality of Life and Sleep Disorders in Patients With a Urostomy: Is There a Relationship? J Wound Ostomy Continence Nurs. 2017, Jul/ Aug;44(4):358-362.

47. Jensen BT, Kiesbye B, Soendergaard I, Jensen JB, Kristensen SA Efficacy of preoperative uro-stoma education on self-efficacy after Radical Cystectomy; secondary outcome of a prospective randomized controlled trial. Eur J Oncol Nurs. 2017, Jun:28:41-46.

48. Glińska J, Hebda A, Dziki A. Impact of nursing care on the quality of life of patients with an enteric stoma. Proktologia. 2005, 6 (3), 232-242.

49. Cierzniakowska K, Kozłowska E, Szewczyk M. Analiza deficytu samoopieki u chorych w oparciu o teorię pielęgniarstwa Dorothy Orem. Piel. Chir. Angiol. 2007, 1, 16-22.

50. Bączyk G, Głowacka A, Kozłowska K, Niewiadomska E. Ocena stopnia samodzielności chorych z przetoką jelitową. Pielęg Pol. 2016, 61 (3), 360-366.

51. Sobczak U. Edukacja pacjenta. [W:] Banasiewicz T, Krokowicz P, Szczepkowski M. (red.). Stomia. Prawidłowe postępowanie chirurgiczne i pielęgnacja. Wydawnictwo Medyczne Termedia. Poznań 2017, 43-46.

52. Cierzniakowska K, Kozłowska E, Szewczyk MT, Banaszkiewicz Z, Szymańska H. Jakość życia pacjentów z wyłonioną stomią jelitową. Pielęgniarstwo Chirurgiczne i Angiologiczne 2013, 4: 142-147.

53. Finlay B, Sexton $H$, McDonald C. Care of patients with stomas in general practice. Aust J Gen Pract. 2018, Jun;47(6):362-365.

54. Danielsen AK, Rosenberg J. Health related quality of life may in crease when patients with a stoma attend patient education-a case-control study. PLoS One. 2014, Mar 7;9(3):e90354

55. Maneesin S, Sampatanukul P, Lertmaharit S, Nagara Ch, Prasopsanti K. Health-related quality of life of patient living with ostomy in Thailand and cost implications. Asian Biomedicine, Vol 6, No. 2 2012, 235-243.
56. Magistri P, Scordamaglia MR, Giulitti D, Papaspyropoulos V Eleuteri E, Coppola M. Patients' quality of life and role of the ambulatory in after-surgery stoma care. A single center experience. Ann Ital Chir. 2014, Mar-Apr;85(2):105-8.

57. Ławnik A. Rehabilitacja pacjentów ze stomią jelitową. Med Og. Nauk. Zdr.2015, 21 (1), 84-87.

58. Glińska J, Jaros A, Lewandowska M, Dziki Ł, Dziki A, Brosowska B. Ocena stopnia satysfakcji z życia u osób ze stomią jelitową w zależności od wybranych czynników demograficznych. Pielęg. Chir. Angiol. 2014, 3, 128-132.

59. Podgórska-Kowalczyk D. Ocena jakości życia chorego ze sztucznym odbytem brzusznym na podstawie wybranych czynników obiektywnych i subiektywnych. Zdr. Publ. 2005, 115(2), 151-154.

60. vanHeinsbergen $M$, Janssen-Heijnen $M L$, Leijtens JW, Slooter $G D$, Konsten JL. Bowel dysfunction after sigmoid resection underestimated: Multicentre study on quality of life after surgery for carcinoma of the rectum and sigmoid. Eur J Surg Oncol. 2018, pii: S0748-7983(18)31053-9.

61. BeaubrunEnFamilleDiant L, Sordes F, Chaubard T. Psychological impact of ostomy on the quality of life of colorectal cancer patients: Role of body image, self-esteem and anxiety. Bull Cancer. 2018, Jun;105(6):573-580.

62. Wrenn SM, Cepeda-Benito A, Ramos-Valadez DI, Cataldo PA Patient Perceptions and Quality of Life After Colon and Rectal Surgery: What Do Patients Really Want? Dis Colon Rectum. 2018, Aug;61(8):971-978.

63. Kozak G. Zróżnicowanie strategii radzenia sobie z nowotworem chorych w przebiegu wybranych nowotworów złośliwych. AnestRatow. 2012, 6:162-170.

64. O'Boyle CA. Assessment of quality of life in surgery. Br I Surg 1992, 79: 395-8

65. Kimura CA, Kamad I, Bellezi Guilhem D. Quality of life in stomized oncological patients: an approach of integrality from Brazilian Unified Health System, j coloproctol (rio j). 2016;3 6(1):34-39.

Zaakceptowano do edycji: 20.08.19 Zaakceptowano do publikacji: 26.09.19

\author{
Adres do korespondencji: \\ Agata Gastecka \\ Katedra Urologii \\ Uniwersytet Mikołaja Kopernika w Toruniu, Collegium Medicum \\ im. Ludwika Rydygiera w Bydgoszczy \\ ul. M.Curie-Skłodowskiej 9 \\ 85-094 Bydgoszcz \\ tel. 525856080 \\ e-mail: agata.gastecka@gmail.com
}

